\title{
What are the expectations of an editor from a scientific article?
}

\author{
O. Şahap Atik, MD \\ Professor of Orthopedic Surgery, Turkish Joint Diseases Foundation, Ankara, Turkey
}

First of all, editors prefer to publish original research and valuable data in all academic journals, ${ }^{[1-3]}$ since readers prefer to read something new and interesting.

Manuscripts may be rejected without peer review by the editor-in-chief if they do not comply with the instructions to authors or if they are beyond the scope of the Journal.

The title of the article should be concise, brief but comprehensive. It must provoke the readers to read the whole article. The title should accurately reflect the outcome of the study. ${ }^{[4]}$ It must be the research question or the answer of it.

The abstract must summarize the manuscript. No discrepancies between the abstract and the article must be. Keywords should be concordant with the National Library of Medicine (NLM) Medical Subject Headings (MeSH) vocabulary terms and three to six keywords should be listed. ${ }^{[5]}$

The study must be based on the review of the medical literature in the introduction. The purpose

Received: July 25, 2020

Accepted: August 28, 2020

Published online: September 11, 2020

Correspondence: O. Şahap Atik, MD. Turkish Joint Diseases

Foundation, Mustafa Kemal Mah., Dumlupınar Bul., 274/2,

C2 Blok, Ofis 5, 06900 Çankaya, Ankara, Türkiye.

E-mail: satikmd@gmail.com

Doi: $10.5606 /$ ehc. 2020.57896

Citation: Atik OŞ. What are the expectations of an editor from a scientific article? Jt Dis Relat Surg 2020;31(3):597-598.

()2020 All right reserved by the Turkish Joint Diseases Foundation

This is an open access article under the terms of the Creative Commons Attribution-NonCommercial License, which permits use, distribution and reproduction in any medium, provided the original work is properly cited and is not used for commercial purposes (http://creativecommons.org/licenses/by-nc/4.0/). of the study must be defined. A hypothesis or a research question must exist. ${ }^{[1-3]}$

The authors must have Informed Consent and Ethical Committee Approval (date and number) in the patients (materials) and methods section. The methods should explain the steps taken to produce the results. It should contain adequate details for other researchers to replicate the study. ${ }^{[1-3]}$

Results must be presented in logical sequence in the text, tables and illustrations. Data in the text should not be repeated in the tables or illustrations. Avoid repeating yourself. ${ }^{[6]}$

In the discussion section, start emphasizing the new and the most important findings of the study. Relate the observations to other relevant studies. Finally, present limitations and conclusion short and clear enough. ${ }^{[7]}$

The format of the references and abbreviated title of the journal must be according to the style used by the PubMed/MEDLINE with year, volume, and inclusive page numbers. Recent references must be preferred.

Illustrations and figures must be original, professionally drawn and photographed with a resolution of $300 \mathrm{DPI}$.

\section{Declaration of conflicting interests}

The authors declared no conflicts of interest with respect to the authorship and/or publication of this article.

\section{Funding}

The authors received no financial support for the research and/or authorship of this article.

\section{REFERENCES}

1. Atik OS. How to write a scientific article?. Eklem Hastalik Cerrahisi 2012;23:60. 
2. Atik OŞ. Which articles do we prefer to publish? Eklem Hastalik Cerrahisi 2018;29:1.

3. Atik OŞ. Is there something new and interesting in my article? Eklem Hastalik Cerrahisi 2019;30:69.

4. Elston DM. Writing a better research paper: Advice for young authors. J Am Acad Dermatol 2019;80:379.
5. Available at: https://www.nlm.nih.gov/mesh/meshhome. html. [Accessed: February 08, 2020]

6. Bahadoran Z, Mirmiran P, Zadeh-Vakili A, Hosseinpanah F, Ghasemi A. The principles of biomedical scientific writing: results. Int J Endocrinol Metab 2019;17:e92113.

7. Villar R. How to write that paper. J Hip Preserv Surg 2020;7:1-3. 